\title{
Hormone inducive effects of Syzygium aromaticum (Clove) extract on the reproductive performance of Bucks
}

${ }^{1}$ *Okukpe, K. M., ${ }^{2}$ Odesanmi, O. M., ${ }^{2}$ Olaniyi, A. W., ${ }^{3}$ Adua, M., ${ }^{1}$ Adeyina, A. O., ${ }^{1}$ Alli, O. I. and ${ }^{1}$ Ajao, B. H.

${ }^{I}$ Reproductive Physiology Unit, Department of Animal Production, Faculty of Agriculture, University of Ilorin, PMB 1515, Ilorin, Kwara State, Nigeria.

${ }^{2}$ Department of Animal Science, University of Ibadan, Ibadan, Oyo State, Nigeria.

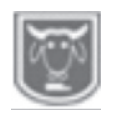

Abstract

${ }^{3}$ Department of Animal Science, Nasarawa State University,

Keffi, Nasarawa State, Nigeria

*Corresponding author: okukpekehinde@yahoo.com.

Syzygium aromaticum (Clove) is a small evergreen tree of the myrtle family known for its unopened reddish-brown flower bud with strong aromatic flavor that are used for culinary purpose and are believed to have aphrodisiac properties. The objective of the experiment was to assess the effect of clove extract on hormone profile of West African Dwarf (WAD) bucks. One hundred and fifty WAD bucks with average weights of $10 \mathrm{~kg}$ were randomly assigned to five treatments with 30 bucks per treatment in a completely randomized design. Treatment $A$ (control) and B were subcutaneously administered $0.1 \mathrm{~mL} / \mathrm{kg}$ of normal saline solution and $0.1 \mathrm{~mL} / \mathrm{kg}$ sildenafil citrate, respectively. Treatments $C$, D and $E$ were administered $0.1,0.2$, and $0.3 \mathrm{~mL} / \mathrm{kg}$ of clove extract, respectively. The result showed a significant increase in WBC while PCV decreased with corresponding increase in extract doses. The extracts also significantly cause a reduction in creatinine, alkaline phosphatase (ALP) and aspartate aminotransferase (AST) with a significant increase in serum urea and alanine aminotransferase (ALT). There were significant increase in serum testosterone and prolactin while follicle stimulating hormone and luteinizing hormone were reduced. It was therefore concluded that subcutaneous administration of syzygium aromaticum extract could enhance sexual function at low doses of $0.1 \mathrm{~mL} / \mathrm{kg}$ body weight of bucks with no observable tissue damage.

Keywords: Hormone, Libido, Bucks, Clove, Extract

\section{Introduction}

The search for aphrodisiacs that could increase libido, potency and sexual pleasure dates back to millennia. Various substances of animal and plant origin have been used in folk medicine of different cultures as aphrodisiacs, some of which have been identified pharmacologically to exert their effects on the hypothalamic-pituitarytesticular axis (Yakubu et al., 2005). Many of such plants with medicinal properties are effective as aphrodisiac through mechanisms such as vasodilation, generation of nitric oxide, elevation of androgens and gonadotropins (Rahimi et al., 2010). It's been reported that sexual behavior and erection are dependent on androgen which may act through central and peripheral mechanisms. Treatments that alter the concentration of circulating sex hormones may also modify sexual behavior. Clinical data on testosterone suggest that a slight increase in the levels of the hormone on adult males results in a moderate but significant increase in sexual desire and libido (Okukpe, 2014). Moreover, many ancient literatures alluded to the use of numerous plant preparations including Syzygium aromaticum (clove) as sex enhancer without any scientific evidence. Clove is the name for a small evergreen tree of the myrtle family and for 


\section{Hormone inducive effects of Syzygium aromaticum (Clove) extract}

its unopened flower bud (Evan, 2009). The reddish-brown flower buds with strong aromatic flavor used dried whole or ground for culinary purposes as well as in synthetic vanilla and other flavoring as well as in perfumes. The oil is extracted for medicinal and antiseptic uses. In order to understand the scientific reasons behind these folk claims, investigation of the effects of ethanolic extract of $S$. aromaticum bud was carried out in this study. The objective of the study therefore, was to determine the effect of clove extracts on some male hormone of West African Dwarf bucks and its reproductive enhancing functions.

\section{Materials and methods}

Source and preparation of extracts: Syzygium aromaticum (Clove) buds were bought in Ilorin, Kwara State, Nigeria. The buds were cleaned, air-dried and ground in a blender (Starlite, Model No: SL-999 CHINA). The extraction of the ground buds was carried out with $96 \%$ ethanol at $75-$ $80^{\circ} \mathrm{C}$ in a Soxhlet apparatus for four hours (Swain, 1999). The liquid was filtered using a $125 \mathrm{~mm}$ Whatman filter paper and the filterate concentrated under reduced pressure in vacuum desiccators. It was dried to a constant weight at $45^{\circ} \mathrm{C}$ in a hot air oven. Subsequently, $5 \mathrm{~g}$ of the extract was dissolved in $250 \mathrm{~mL}$ of normal saline to obtain appropriate concentration suitable to achieve $0.5 \mathrm{~mL}$ dose by volume of extract which was later administered subcutaneously to the bucks for a period of 4days.

Experimental animal management: A total of 15 WAD bucks of $1-2$ years old with an average weight of $10 \mathrm{~kg}$ were quarantined for a period of 14 days before the start of the experiment in pens with slatted wooden floors. They were administered Oxyletic $\AA$, vitamin and ivomec $\AA$ to relieve them from stress, external and internal parasites. They were also vaccinated against Pestes des petits ruminatum (PPR) using Tissue Culture Rinderpest Vaccine (TCRV). They were fed $300 \mathrm{~g}$ of concentrated feed per day with the composition in Table 1 after provision of Panicum maximum and water. Experimental design: The experiment followed a completely randomized design (CRD). Animals were assigned to five experimental groups (A, B, C, D and E) made up of three animals per treatment. Group A (control) were given $0.1 \mathrm{~mL} / \mathrm{kgBW}$ of normal saline, group B (positive control) were given Sildenafil-citrate drug at manufacturers recommendation, while groups $\mathrm{C}, \mathrm{D}$ and $\mathrm{E}$ were subcutaneously injected with $0.1,0.2$ and $0.3 \mathrm{~mL} / \mathrm{kgBW}$ of the extract daily for four consecutive days. Blood samples were collected at the beginning and end of experiment through the jugular vein for haematology and biochemical analysis. The scrotal length, circumference and rectal temperature were also monitored.

Statistical analysis: The experiment followed a completely randomized design (CRD). The data obtained were analyzed by the Generalized Linear Model procedures of SAS version 9.2 software (Statistical Analysis System, SAS Institute Inc, Cary, NC, USA) (SAS, 2008). Mean differences were considered significant at $\mathrm{p}<0.05$ and separated by Duncan multiple range test.

\section{Discussion}

The effects of Syzygium aromaticum extract on haematology showed a significantly low PCV with increase in the extract doses, though higher than the positive control (Sildenafil citrate). A reduction in PCV may be as a result of destruction of the cells, reduced production or a destruction of the organs involved in their production. Although, it changes with breeds and species of animals, it is often influenced by the state of health of the animal (Ganong, 2005). The PCV values of animals in groups 
Okukpe, Odesanmi, Olaniyi, Adua, Adeyina, Alli and Ajao

Results

Table 1: The composition of experimental feed

\begin{tabular}{lr}
\hline Ingredients & \% Composition \\
\hline Maize & 30.00 \\
Groundnut & 14.00 \\
Wheat offal & 33.00 \\
Salt & 1.00 \\
Premix (vitamin/mineral) & 0.25 \\
Rice bran & 10.00 \\
Limestone & 1.00 \\
Bone & 0.75 \\
Palm-kernel cake & 10.00 \\
Total & 100.00 \\
Nutrient contents & \\
Energy (cal) & 2257.48 \\
Crude protein & 17.30 \\
Crude fibre & 7.04 \\
Ash & 4.70 \\
\hline
\end{tabular}

Table 2: Effect of Syzygium aromaticum (clove) extract on haematology of West African dwarf bucks

\begin{tabular}{|c|c|c|c|c|c|c|}
\hline Parameters & $\begin{array}{l}\text { A } \\
(0.1 \mathrm{~mL} \text {-saline } \\
\text { water) }\end{array}$ & $\begin{array}{l}\text { B } \\
(0.1 \mathrm{~mL}-\mathrm{Sc})\end{array}$ & $\begin{array}{l}\text { C } \\
(0.1 \mathrm{~mL}-S a \\
\text { extract) }\end{array}$ & $\begin{array}{l}\text { D } \\
(0.2 \mathrm{~mL}-S a \\
\text { extract })\end{array}$ & $\begin{array}{l}\mathrm{E} \\
(0.3 \mathrm{~mL}-\mathrm{Sa} \\
\text { extract) }\end{array}$ & $\ldots$ \\
\hline PCV, \% & $31.00^{\mathrm{a}}$ & $21.00^{\mathrm{bc}}$ & $25.00^{\mathrm{c}}$ & $16.00^{\mathrm{b}}$ & $27.00^{\mathrm{ab}}$ & 1.47 \\
\hline $\mathrm{Hb}, \mathrm{g} / \mathrm{dL}$ & 10.30 & 8.60 & 8.30 & 5.30 & 9.00 & 1.10 \\
\hline $\mathrm{RBC}, \times 10^{6} / \mathrm{L}$ & 5.20 & 3.18 & 5.00 & 6.50 & 14.20 & 1.42 \\
\hline $\mathrm{WBC}, \times 10^{9} / \mathrm{L}$ & $10.40^{\mathrm{b}}$ & $12.40^{\mathrm{b}}$ & $10.00^{\mathrm{b}}$ & $12.20^{\mathrm{b}}$ & $27.00^{\mathrm{a}}$ & 1.15 \\
\hline Neutrophil, \% & 48.00 & 40.00 & 58.00 & 50.00 & 61.00 & 2.42 \\
\hline Eosinophil, \% & 0.00 & 2.00 & 2.00 & 1.00 & 3.00 & 0.43 \\
\hline Monocyte, \% & 10.00 & 5.00 & 8.00 & 4.00 & 5.00 & 1.12 \\
\hline Basophil, \% & 2.00 & 1.00 & 2.00 & 2.00 & 1.00 & 0.41 \\
\hline
\end{tabular}

Table 3: Effects of Syzygium aromaticum (clove) extract on some bioch emical indices of West African dwarf bucks

\begin{tabular}{|c|c|c|c|c|c|c|}
\hline Parameters & $\begin{array}{l}\text { A } \\
(0.1 \mathrm{~mL} \\
\text { saline } \\
\text { water })\end{array}$ & $\begin{array}{l}\quad \text { B } \\
(0.1 \mathrm{~mL}- \\
\text { Sc) }\end{array}$ & $\begin{array}{l}\mathrm{C} \\
(0.1 \mathrm{~mL}-\mathrm{Sa} \\
\text { extract) }\end{array}$ & $\begin{array}{l}\text { D } \\
(0.2 \mathrm{~mL}-\mathrm{Sa} \\
\text { extract) }\end{array}$ & $\begin{array}{l}\mathrm{E} \\
(0.3 \mathrm{~mL}-\mathrm{Sa} \\
\text { extract) }\end{array}$ & $\begin{array}{l} \pm \\
\text { SEM }\end{array}$ \\
\hline Urea, mg/dL & $301.20^{\mathrm{c}}$ & $373.70^{\mathrm{a}}$ & $373.70^{\mathrm{a}}$ & $336.40^{b}$ & $239.50^{d}$ & 8.70 \\
\hline $\begin{array}{l}\text { Creatinine } \\
\mathrm{mg} / \mathrm{dL}\end{array}$ & $2.25^{\mathrm{a}}$ & $1.77^{\mathrm{b}}$ & $1.77^{\mathrm{b}}$ & $0.83^{\mathrm{c}}$ & $0.77^{\mathrm{c}}$ & 0.13 \\
\hline $\begin{array}{l}\text { Bilirubin, } \\
\mathrm{mg} / \mathrm{dL}\end{array}$ & 4.71 & 4.34 & 4.34 & 4.21 & 4.30 & 0.29 \\
\hline ALP, IU/L & $133.30^{\mathrm{b}}$ & $176.90^{\mathrm{a}}$ & $176.90^{\mathrm{a}}$ & $124.50^{\mathrm{b}}$ & $132.70^{\mathrm{b}}$ & 5.59 \\
\hline ALT, IU/L & $4.46^{\mathrm{d}}$ & $7.46^{\mathrm{c}}$ & $7.46^{\mathrm{c}}$ & $14.19^{\mathrm{a}}$ & $10.09^{b}$ & 0.50 \\
\hline $\mathrm{AST}, \mathrm{IU} / \mathrm{L}$ & $7.81^{\mathrm{b}}$ & $9.23^{\mathrm{a}}$ & $10.22^{\mathrm{a}}$ & $7.72^{\mathrm{b}}$ & $4.63^{c}$ & 0.29 \\
\hline $\begin{array}{l}\text { Testosterone, } \\
\mathrm{ng} / \mathrm{mL}\end{array}$ & $7.21^{b}$ & $8.15^{\mathrm{a}}$ & $8.15^{\mathrm{a}}$ & $6.61^{\mathrm{c}}$ & $6.10^{\mathrm{d}}$ & 0.14 \\
\hline FSH, $\mathrm{mIU} / \mathrm{mL}$ & $1.26^{\mathrm{b}}$ & $4.33^{\mathrm{a}}$ & $0.11^{\mathrm{d}}$ & $0.13^{\mathrm{d}}$ & $0.80^{\mathrm{c}}$ & 0.08 \\
\hline $\mathrm{LH}, \mathrm{mIU} / \mathrm{mL}$ & $3.66^{\mathrm{a}}$ & $2.16^{\mathrm{b}}$ & $2.31^{\mathrm{b}}$ & $2.62^{\mathrm{b}}$ & $1.16^{\mathrm{c}}$ & 0.14 \\
\hline PRL, ng/mL & $0.56^{\mathrm{b}}$ & $0.20^{\mathrm{d}}$ & $0.36^{\mathrm{c}}$ & $0.86^{\mathrm{a}}$ & $0.21^{\mathrm{d}}$ & 0.04 \\
\hline
\end{tabular}




\section{Hormone inducive effects of Syzygium aromaticum (Clove) extract}

$\mathrm{B}$ and $\mathrm{C}$, though significantly low when compared with the control was similar to the normal values of $25.7 \pm 3.1 \%$ reported by Tambuwal et al. (2002) and Okukpe et al. (2014).

Similarly, there were numerical differences in $\mathrm{RBC}$ values for the extract levels, though not significant, this could be adduced to the haemopoietic effects of the extract, thus Syzygium aromaticum extract could increase red blood cells production. The increase in WBC observed in the extract administered treatments might be due to the stimulation of the cells for the production and mobilization of leucocytes to counter the stress and defend against the animals' hyperactivity resulting from the use of the extract. An increase in WBC as been reported to indicate a defense against infection or to counter stress or exercise. Sexual stimulation involves the tensing of body muscles, an increase in energy dissipation which may result in an increased WBC (Ganong, 2005; Okukpe et al., 2015). The numerical increase in neutrophil may be due to the fact that it accounts for the largest percentage of the total WBC while monocyte, basophil and eosinophil decreases gradually as the level of dosage of extract increases (Hafez and Hafez, 2000). The result shows that the animal may not necessarily be having an infection but may be due to sexual response as a result of increased libido. Bilirubin is produced as a result of breakdown of haemoglobin pigment in the body of the animal. Bilirubin level is related to the function of hepatic cells. Bilirubin level was observed to reduce with increase in extract administration. This indicates that the extract stimulates proper functioning of the hepatic cells (Ganong, 2005; Okukpe et al., 2015). Serum Urea, a product of protein and amino-acid catabolism, decreased with increasing level of extract. Excess urea in the body is a sign of excess protein production, increased catabolism or malfunctioning of the liver and kidney (Spector et al., 2007; Ilesanmi, 2009). It was observed that urea formed at high Syzygium aromaticum extract doses was adequately excreted. This indicates that it has no negative effects on the kidney and liver function of the animal. This was similar to the observed liver enzymes. Aspartate aminotransferase (AST), has been reported to increase as a result of injury to liver, muscles or bone cells. It was observed that it decreased with increasing extract administration showing the extract had minimal negative effect on the liver, kidney, muscles and bone cells at the doses administered (Fairbank and Klee, 1986). Alanine aminotransferase (ALT), which is more specific to the liver and thus a better parameter for detecting liver injury (Moss and Butterworth, 1974) increased with increasing doses of the extract. According to Edwards et al. (1995), the liver enzymes (ALT and AST) are liberated into the blood whenever liver cells are damaged and enzyme activity in the blood is increased. The fact that the enzyme activity was reduced at $0.3 \mathrm{~mL} / \mathrm{kg}$ body weight indicates that the extract had minimal negative effect on the liver. This might not be unconnected with the antioxidants and hepatoprotective activity of the extracts (Tajuddin et al., 2005; Evans, 2009).

Accurate determination of creatinine clearance is crucial to rational drug therapy because many drugs are either partially or totally eliminated by the kidney (Schalm et al., 2010). Blood Urea, nitrogen and creatinine are most effectively used as renal function tests (Duncan et al., 1994; Ganong, 2005). Creatinine was observed to decrease with increased extract doses indicating that it has minimal effect on muscle integuity.

Testosterone level was observed to decrease with increasing in doses. This indicates that Syzygium aromaticum extract had no effect 


\section{Okukpe, Odesanmi, Olaniyi, Adua, Adeyina, Alli and Ajao}

on sexual performance at the doses used, though higher doses could show promise in enhancement of sexual performance of bucks which is essential for the development of male sexual characteristics and sperm production. Follicule stimulating hormone (FSH) increased with increasing level of extract indicating that the extract could stimulate the development of primary spermatocytes in bucks (Okukpe et al., 2015). Luteinizing hormone (LH) on the other hand was observed to reduce with increasing extract doses. This indicates that the production of testosterone by the leydig cells could be inhibited with increase in the level of extract (Hafiez et al., 1972). Prolactin (PRL) was observed to decrease with increasing level of extract, indicating that the extract could be used to prolong the duration of mating as a reduction in the level of prolactin has been reported to increase the duration of mating (Thakur and Paramanik, 2009).

\section{Conclusion}

The study showed that Syzygium aromaticum extract had no negative effect on the haematology and biochemical parameters studied as well as on the liver enzymes. Low levels of the extract could increase steroidal hormone and also help to enhance reproductive performance.

\section{References}

Duncan, J. R., Prasse, K. W. and Mahaffey, E. A. 1994. Veterinary Laboratory Medicine (Clinical pathology), Iowa State University Press.

Evan, W. C. 2009. Trease and Evans Pharmacognosy, $16^{\text {th }}$ edition, Saunders Elsevier Ltd pub. Edinburgh, pp305.

Fairbanks, V. F. and Klee, G. G. 1986. Biochemical aspects of haematology.In: Tietz N.W. (Ed.),
Textbook of Clinical Chemistry. Saunders Company, Philadelphia, pp1498-1533.

Ganong, W. F. 2005. Review of Medicinal Physiology, $22^{\text {nd }}$ Edition, McGrawHill Companies Inc., Singapore, pages $25-557$.

Hafez, B. and Hafez, E. S. E. 2000. Functional Anatomy of Male reproduction. In: Reproduction in Farm Animals. Williams and Wilkins, Lippincoff, pp17, 512.

Hafiez, A. A., Lloyd, C. W. and Bartke, A. 1972. The role of prolactin in the regulation of testes function: The effects of prolactin and luteinizing hormone on the plasma levels of testosterone and androstenedione in hypophysectomized rats. Journal of Endrocrinology 52: 327-332.

Ilesanmi, A. O. 2009. A Handbook of Laboratory Tests for Health Practitioners. J. Ochei, A. Emeribe, T. Anifowose, A. Onyeaghala and Z.A. Jeremiah (Eds), Claverianum Centre, Bodija, Ibadan,pp110-161.

Moss, D. W. and Butterworth, P. J. 1974. Enzymology and medicine, Pitman medical, London. Page 139

Okukpe, K. M., Adeyemo, A. D., Adua, M., Omotayo, O. O., Yusuf, O. A., Aderibigbe, T. A., Opowoye, I. O., Ogunsola, F. O. and Osho, B. 2016. Stress Modulating Effect of Crude Leaf Extract of Vernonia amygdalina in Captive Grasscutter (Thryonomys swinderianus). Wayamba Journal of Animal Science 1471804739: P1445 P1459.

Okukpe, K. M., Adeyina, O. A., Olatunde, O. A. and Alli, O. I. 2015. Fundamentals of Anatomy and Physiology of Farm Animals. OLAD pub. Nig. Pg 67 ISBN: 978978-53588-1-0 
Okukpe, K. M., Adeloye, A. A. and Soladoye, A. O. 2014.Effects of Varying Levels of Mucuna pruriens Extract on Reproductive Performance of West African Dwarf Bucks. Centrepoint Journal (Science Edition). 20 (2): 95 - 102.

Rahimi, R., Ghiasi, S., Azimi, H., Fakhari, S. and Abdollahi, M. 2010. A review of the herbal phosphodiesterase inhibitors: Future perspective of new drugs. Cytokine 49: 123-129.

SAS 2008. SAS Institute Inc. 2008. ASA/STAT users Guide version 9.2 for windows. Carry, North Carolina, USA. SAS Institute Inc.

Schalm, O. W., Jain, N. C. and Carroll, E. J. 2010. Veterinary haematology. $5^{\text {th }}$ edition, Lea and Febiger, Philadelphia, USA, pp13, 123, 136.

Spector, O. W., Yang, Q., Wade, J. B. 2007. High Urea and Creatinine concentrations and Urea transporter $\mathrm{B}$ in mammalian urinary tract tissues. American Journal of Renal Physiology 292 (1): F467-F474.

Swain, I. E. 1999. Phytochemical analysis. Academic Press, London, pp33-88
Tajuddin, S., Ahmad, S., Latif, A., Qasmi, I. A. and Amin, K. M. 2005. An experimental study of sexual functions improving effect of Myristica Fragrans, Houtt. BMC Complement Alternative Medicine $5: 16$.

Tambuwal, F. M., Agale, B. M. and Bangana, A. 2002. Haematological and Biochemical values of apparently healthy Red Sokoto goats. Proceeding of $27^{\text {th }}$ Annual Conference of Nigerian Society for Animal Production (NSAP) March, 17-21, 2002, FUT, Akure, Nigeria, pp50-53.

Thakur, M. K. and Paramanik, V. 2009. Role of Steroid hormone coregulators in health and diseases. Hormone Research 71 (4): 194 200.

Yakubu, M. T., Akanji, M.A. and Oladiji, A. T. 2005. Aphrodisiac potentials of aqueous extract of Fadogia agrestis (Schweinf. Ex Hiern) stem in male albino rats. Asian Journal of Andrology 7 (4): 399-404.

Received: $7^{\text {th }}$ September, 2018 Accepted: $20^{\text {th }}$ December, 2018 